\title{
InTercropping Corn With a Combination of Tree Species to CONTROL WeEds ${ }^{1}$
}

\author{
Consorciação do Milho com Uma Combinação de Espécies Arbóreas para Controlar Plantas \\ Daninhas
}

\begin{abstract}
SILVA, P.S.L. ${ }^{2}$, SILVA, E.M. ${ }^{2}$, SILVA, P.I.B. ${ }^{2}$, FERNANDES, J.P.P. ${ }^{2}$, and CHICAS, L.S. ${ }^{3}$
ABSTRACT - The combination of crop residues or crop extracts is often more advantageous in controlling weeds, than the application of each residue or extract singly. This suggests that in intercropping with maize, the combination of tree species can be more advantageous than species isolated in weed control. The objective of this study was to evaluate the effects of intercropping with a combination of leguminous on the weed growth and corn yield. A randomized-block design with split plots (cultivars in plots) and five replicates was established. The cultivars BR 205 and AG 1041 were subject to the following treatments: two weedings (A), intercropping with sabiá (B), gliricidia (C), gliricidia + sabiá (D) and no weeding (E). In the $\mathrm{B}$ and $\mathrm{C}, 30$ viable seeds $\mathrm{m}^{-2}$ of the leguminous were sown. In the $\mathrm{D}, 15$ seeds of each species were sown $\mathrm{m}^{-2}$. The legumes were sown by random casting during corn planting. The sequence of the best treatments in reducing the growth of weeds is $\mathrm{A}>\mathrm{B}=\mathrm{C}=\mathrm{D}=\mathrm{E}$. The sequence of the best treatments when are considered the yields of baby corn, green corn and grain is $\mathrm{A}>\mathrm{B}>\mathrm{C}>\mathrm{D}>\mathrm{E}$. The cultivars do not differ in regards to the reduction in weed growth. In terms of corn yield cultivar BR 205 is the best.
\end{abstract}

Keywords: Zea mays, Gliricidia sepium, Mimosa caesalpiniifolia, green corn, grain yield.

\begin{abstract}
RESUMO - A combinação de residuos ou extratos das culturas frequentemente é mais vantajosa do que a aplicação isolada dos resíduos ou extratos, no controle das plantas daninhas. Isso sugere que, na consorciação com o milho, a combinação de espécies arbóreas pode ser mais vantajosa do que espécies isoladas no controle de plantas daninhas. O objetivo deste estudo foi avaliar os efeitos da consorciação do milho com uma combinação de leguminosas arbóreas sobre o crescimento das plantas daninhas e o rendimento do milho. Utilizou-se o delineamento de blocos casualizados com parcelas subdivididas (cultivares nas parcelas) e cinco repetições. Os cultivares BR 205 e AG 1041 foram submetidos aos seguintes tratamentos: duas capinas (A), consorciação com a sabiá (B), consorciação com a gliricídia (C), consorciação com a sabiá + gliricídia (D) e sem capinas (E). Em Be $C$ foram semeadas 30 sementes das leguminosas $m^{-2}$. Em D, foram semeadas 15 sementes de cada espécie $\mathrm{m}^{-2}$. As leguminosas foram semeadas a lanço durante a semeadura do milho. Os melhores tratamentos para redução do crescimento das plantas daninhas são: $A>B=C=D=E$. Os melhores tratamentos, quando considerados os rendimentos de minimilho, milho verde e de grãos, foram: $A>$ $B>C>D>E$. Os cultivares não diferem na redução do crescimento das plantas daninhas. Quanto ao rendimento de milho, o cultivar BR 205 é o melhor.
\end{abstract}

Palavras-chave: Zea mays, Gliricidia sepium, Mimosa caesalpiniifolia, milho verde, rendimento de grãos.

Recebido para publicação em 3.5.2015 e aprovado em 17.7.2015.

2 Universidade Federal Rural do Semi-Árido, Mossoró-RN, Brazil, <paulosergio@ufersa.edu.br>; ${ }^{3}$ Universidade Federal do Ceará, Fortaleza-CE, Brazil. 


\section{INTRODUCTION}

The weed control in the Brazilian semiarid region is mostly done with hoeing and herbicide use. The hoeings are used by most small farmers, but are problematic because they are time consuming, expensive and laborious. The use of herbicides is done by most large companies, but also presents difficulties due to a probably contamination that cause to the air, soil and water, and the negative implications to the health of humans and other animals. Furthermore, the use of the same herbicides for many years is resulting in the selection of weed biotypes resistant to them.

The problems associated with weeding and herbicide use and the pressure from societies for more sustainable agriculture has led to the search for and reevaluation of alternative methods for weed control. Various methods include soil covering (Rajashekarappa et al., 2013), incorporation of plant residues (Matloob et al., 2010; Khaliq et al., 2011), spraying with vegetable extracts (Mubeen et al., 2012; Uddin et al., 2013), and intercropping (Tavella et al., 2014).

Intercropping to control weeds has mainly been attempted with annual crops. However, several studies have demonstrated that various perennial species may control weeds when grown with corn (Tavella et al., 2014). In these studies, corn has been intercropped with tree species individually, i.e., corn + gliricidia (Gliricidia sepium) or corn + sabiá (Mimosa caesalpiniifolia).

Analyses of other weed control methods have frequently included a combination of treatments, for example, combinations of residues products (Matloob et al., 2010; Khaliq et al., 2011) or plant extracts (Khan et al., 2005; Mubeen et al., 2012; Uddin et al., 2013) from various crops. Applications of combinations are based on the fact that the allelochemicals from a given species differentially affect other species (Ebana et al., 2001). That is, there are interspecific and intraspecific differences in allelopathic potential (Ebana et al., 2001; Imatomi et al., 2013). Conversely, the allelopathy of a given species may influence various species differently (Uddin et al., 2013).
The results obtained with the combination of crop residues or combination of crop extracts are often more advantageous in controlling weeds than the application of residues or extracts individually. This suggests that it would be interesting to evaluate the combination of two or more species intercropped with the main crop, to measure the effects of it on weed control and crop yield. For example, corn + (gliricidia + sabiá).

The objective of this study was to evaluate the effects of intercropping with a combination of gliricidia + sabiá on weeds and corn yields.

\section{MATERIAL AND METHODS}

The studies were carried out on the Rafael Fernandes Experimental Farm of the Federal Rural University of the Semi-Arid (UFERSA) from October 2012 to February 2013. This farm is located in the district of Alagoinha, $20 \mathrm{~km}$ from the town of Mossoró $\left(5^{\circ} 11^{\prime} \mathrm{S}, 37^{\circ} 20^{\prime} \mathrm{W}\right.$, at an elevation of $18 \mathrm{~m}$ ) in the state of Rio Grande do Norte, Brazil. Under the Gaussen bioclimatic system, the climate in the region of Mossoró is classified as type 4ath, distinctly xerothermic (i.e., tropical hot), with a pronounced dry season lasting from seven to eight months, and a xerothermic index of between 150 and 200. The region has a maximum average air temperature of between 32.1 and $34.5{ }^{\circ} \mathrm{C}$ and an average minimum of between 21.3 and $23.7^{\circ} \mathrm{C}$, with June and July being the coldest months. The average annual rainfall is approximately $825 \mathrm{~mm}$. Sunlight increases from March to October, with an average of $241.7 \mathrm{~h}$; the maximum relative humidity reaches $78 \%$ in April with a minimum of $60 \%$ in September (Carmo Filho et al., 1989).

The soil in the area is classified as a Red-Yellow Argisol (RYA) (Embrapa, 2006). Analysis of the experimental soil indicated that it had a pH of 6.46 and its phosphorous, potassium, and sodium levels were 6.4, 85.3, and $66.3 \mathrm{mg} \mathrm{dm}^{-3}$, respectively. The contents of calcium, magnesium, aluminum, hydrogen, total bases, and exchangeable bases and the cation exchange capacity were $1.69,1.00$, $0.00,0.74,3.20,3.20$ and $3.94 \mathrm{cmol}_{\mathrm{c}} \mathrm{dm}^{-3}$, respectively. The percentages of base saturation and exchangeable sodium were $81 \%$ and $7 \%$, respectively. 
The area was prepared by performing two harrowings before a starter fertilizer was applied based on the results of the soil analysis and corn needs; the resulting fertilizer N, P, and $\mathrm{K}$ quantities were estimated to be 120 , 60 and $30 \mathrm{~kg} \mathrm{ha}^{-1}$, respectively. The sources of $\mathrm{N}, \mathrm{P}$, and $\mathrm{K}$ were ammonium sulfate, superphosphate and potassium chloride, respectively. Fertilizers were applied in furrows located to the side and below the seed furrows. One-third of the nitrogen was applied during the starter fertilizer application and the other $2 / 3$ was applied as top-dressing at 25 days and 45 days after sowing, after the completion of weeding.

A completely randomized-block experimental design with five replicates and subdivided plots was used. Each plot contained the hybrids AG 1051 and BR 205. The following weed control methods were used on the subplots: no weeding; two weedings (at 20 and 40 days after corn sowing, DACS); intercropping with gliricidia (Gliricidia sepium); intercropping with sabiá (Mimosa caesalpiniifolia); and intercropping with gliricidia + sabiá. For the single-species intercroppings, 30 viable seeds were sown per $\mathrm{m}^{2}$. For the gliricidia + sabiá intercropping, 15 viable seeds of each species were sown per $\mathrm{m}^{2}$. Seeds were sown by casting to ensure a uniform distribution and incorporated using a rake.

The spacing between rows was $1.0 \mathrm{~m}$, with the holes in any one row spaced $0.40 \mathrm{~m}$ apart. Sowing was performed manually with four seeds per hole. At 20 days after sowing, the plants were thinned, leaving the two largest plants in each hole and giving the experiment a planned seeding density of 50 thousand plants $\mathrm{ha}^{-1}$.

Each subplot consisted of five $6.0 \mathrm{~m}$ long rows. Only the three central rows were sampled, from which the plants from one hole at the three row ends were discarded at harvest. Of the three central rows in each experimental unit, one was used to estimate baby corn yield, another for green ear yield, and the last for corn grain yield.

The experiment was conducted under sprinkler irrigation. The depth of water needed by the maize $(5.3 \mathrm{~mm})$ was calculated taking the effective depth of the root system to be $0.40 \mathrm{~m}$. When to irrigate was based on the water retained in the soil at a pressure of $0.40 \mathrm{Mpa}$. Irrigation began after sowing was carried out three times a week and was suspended five days before the mature ears were harvested. Fall armyworms (Spodoptera frugiperda) were controlled by two applications of Decis $25 \mathrm{CE}$ (deltamethrin, $250 \mathrm{~mL}$ i.a. ha ${ }^{-1}$ ) at 25 and 45 days after sowing. Corn leafhopper (Dalbulus maidis), was controlled by spraying with Decis $25 \mathrm{CE}$ at 45 days after sowing.

The following characteristics of the sabia plants were analyzed: number of plants per $\mathrm{m}^{2}$, plant height, and root collar diameter at 110 days after sowing. The weeds growing in the plots were collected from a $1.00 \mathrm{~m} \times 0.8 \mathrm{~m}$ area between two rows of corn at 110 days after corn planting. Weeds were cut at the soil level, identified, and ground. A sample of the aboveground material weighing approximately $200 \mathrm{~g}$ was placed into an oven to determine dry mass.

Eight baby corn harvests were conducted from 52 to 66 days after sowing, and all were performed three days after emergence of the silk. The number and mass of the unhusked ears, as well as the fresh and dry mass of the husked ears, were assessed. Marketable unhusked ears were defined as those free of pest damage or disease, while marketable husked ears were those with good health, pearl white to light yellow color, a cylindrical shape, diameters between $8 \mathrm{~mm}$ and $18 \mathrm{~mm}$, and lengths between $4 \mathrm{~cm}$ and $12 \mathrm{~cm}$ (Silva et al., 2006). Dry masses of husked ears were estimated by placing them in a forced-air oven at $75{ }^{\circ} \mathrm{C}$ until achieving a constant mass.

Two harvests of green ears were collected, at 74 and 76 days after sowing, when the corn grains had a moisture level between approximately $70 \%$ and $80 \%$. The number and total mass of the green ears, as well as the number and mass of the marketable green ears, with and without husks, were assessed. Marketable unhusked green ears were defined as those free of pest damage or disease, with no defects, and with lengths equal to or greater than $22 \mathrm{~cm}$. The number and mass of marketable husked green ears, considered to be those with good health and corn grain formation and a length equal to or greater 
than $17 \mathrm{~cm}$, were also recorded (Silva et al., 2006).

Dry corn was harvested 118 days after sowing, when the grains had a moisture level of $20 \%$. The heights of the plants and of the insertion points of the ears, the numbers of ears and of grains per ear, the weight per 100 grains, and the corn grain yield were assessed. Plant height was defined as the distance from the soil surface to the insertion point of the highest leaf. The height of the insertion point of an ear was measured from the soil surface to the base of the highest ear, in the case of prolific plants. The number of grains was estimated by counting the number of grains in one row of each ear and the number of rows per ear. The weight of 100 grains was estimated by summing the weight of the grains in an ear divided by the number of grains in the ear. Corn grain yield was corrected assuming a moisture level of $15.5 \%$.

Data from the maize and weeds were submitted to a test for homogeneity of variance prior to variance analysis ( $\mathrm{F}$ test). The means were compared at $5 \%$ probability by Tukey test.

\section{RESULTS AND DISCUSSION}

In the dry aboveground biomass of weeds there was effect of methods of weed control, but there was no effect for cultivars. In the plots planted with cultivars BR 205 and
AG 1041, the mean dry biomasses of the weeds were $392.2 \mathrm{~g}$ and $431.4 \mathrm{~g} \mathrm{~m}^{2}$, respectively, which were not significantly different. In the plots that received two weedings, the dry biomasses of the weeds were less than those of the plots with the other treatments, which were not different from each other (Table 1). The most common weed species in the 50 experimental units were (frequency, in percentage of experimental units) Ipomoea sp. (78\%), Adenocalymma sp. (66\%), Cenchrus echinatus (66\%), Paspalum griseum (64\%), and Solanum agrarium (42\%). Another 17 species were found at frequencies less than $30 \%$.

The analysis of variance for numbers of plants $\mathrm{m}^{-2}$, plant heights, and root collar diameters of the legumes analyzed indicated an effect only for cultivation system (corn sabiá, corn - gliricidia, and corn - sabiá + gliricidia). Therefore, these characteristics were not affected by the corn cultivars. In all of the cultivation systems, the survival of the legumes, and possibly their growth, were decreased (as sabiá and gliricidia were not grown in the absence of weeds, comparisons could not be made) (Table 2). Decreases were caused probably by allelopathy and competition for growth with weeds and with corn. Several authors have found that weeds reduce forest species survival and growth when sown directly, similar to what was done in this study (Valkonen, 2008; Wang et al., 2011). Sabiá tolerated interference with weeds and corn

Table 1 - Mean for weed above-ground dry mass and plant height and ear height of corn cultivars as a response to weed control methods $\underline{1}^{\prime \prime}$

\begin{tabular}{|c|c|c|c|c|c|}
\hline \multirow{3}{*}{ Weed control methods ${ }^{\underline{2} /}$} & \multirow{3}{*}{$\begin{array}{l}\text { Dry weed biomass } \\
\qquad\left(\mathrm{g} \mathrm{m}^{-2}\right)\end{array}$} & \multicolumn{2}{|c|}{ Plant height $(\mathrm{cm})$} & \multicolumn{2}{|c|}{ Ear height (cm) } \\
\hline & & \multicolumn{2}{|c|}{ Corn cultivars } & \multicolumn{2}{|c|}{ Corn cultivars } \\
\hline & & BR 205 & AG 1041 & BR 105 & AG 1041 \\
\hline Two hoeings & $117.7 \mathrm{~b}$ & $147 \mathrm{Ac}$ & $162 \mathrm{Aab}$ & $70 \mathrm{Bb}$ & $90 \mathrm{Aab}$ \\
\hline Sabiá intercropping & $437.3 \mathrm{a}$ & 170 Aab & 175 Aab & $88 \mathrm{Aab}$ & $100 \mathrm{Aab}$ \\
\hline Gliricidia intercropping & $497.4 \mathrm{a}$ & 160 Abc & $172 \mathrm{Aab}$ & $83 \mathrm{Bb}$ & $98 \mathrm{Aab}$ \\
\hline Sabiá + gliricidia intercropping & $520.3 \mathrm{a}$ & $185 \mathrm{Aa}$ & $160 \mathrm{Bb}$ & $105 \mathrm{Aa}$ & $83 \mathrm{Bb}$ \\
\hline No hoeing & $486.2 \mathrm{a}$ & $164 \mathrm{Bbc}$ & $181 \mathrm{Aa}$ & $80 \mathrm{Bb}$ & $104 \mathrm{Aa}$ \\
\hline $\mathrm{CV}_{\text {plots }}(\%)$ & 37.9 & \multicolumn{2}{|c|}{9.2} & \multicolumn{2}{|c|}{13.6} \\
\hline $\mathrm{CV}_{\text {subplots }}(\%)$ & 36.0 & \multicolumn{2}{|c|}{6.9} & \multicolumn{2}{|c|}{11.3} \\
\hline
\end{tabular}

1/ Means followed by the same upper case letter in the row, and by the same lower case letter in the column do not differ from one another at $5 \%$ probability, by Tukey's test. ${ }^{2 /}$ In the intercrop treatments, the leguminous species were broadcasting sowed between corn rows, simultaneously when the corn was sowed. The sowing rate for gliricidia (Gliricidia sepium) and sabiá (Mimosa caesalpiniifolia) intercrops was 30 iable seeds $^{-2}$. The sowing rate for corn + gliricidia + sabiá intercrop was 15 iable seeds ${ }^{-2}$ of each leguminous species. 
Table 2 - Means for leguminous species traits at intercropping with corn cultivars for weed control ${ }^{1 /}$

\begin{tabular}{|c|c|c|c|c|c|}
\hline \multirow{2}{*}{ Intercroppings $^{\underline{\underline{2}}}$} & \multirow{2}{*}{$\begin{array}{c}\text { Leguminous } \\
\text { species evaluated }\end{array}$} & \multicolumn{2}{|c|}{ Plant number $\mathrm{m}^{-2}$} & \multirow{2}{*}{$\begin{array}{l}\text { Plant height } \\
(\mathrm{cm})\end{array}$} & \multirow{2}{*}{$\begin{array}{l}\text { Root collar } \\
\text { diameter } \\
\quad(\mathrm{mm})\end{array}$} \\
\hline & & $\begin{array}{c}\text { Original data } \\
(\mathrm{x})\end{array}$ & $\begin{array}{l}\text { Transformed data } \\
\text { (?x) }\end{array}$ & & \\
\hline Corn + sabiá & Sabiá & 10.4 & $3.2 \mathrm{a}$ & $47.3 \mathrm{a}$ & $2.9 \mathrm{~b}$ \\
\hline Corn + sabiá + gliricidia & Sabiá & 4.2 & $2.1 \mathrm{ab}$ & $39.1 \mathrm{ab}$ & $4.9 \mathrm{a}$ \\
\hline Corn + gliricidia & Gliricídia & 5.8 & $2.4 \mathrm{~b}$ & $41.9 \mathrm{ab}$ & $2.6 \mathrm{~b}$ \\
\hline Corn + sabiá + gliricidia & Gliricídia & 3.3 & $1.8 \mathrm{c}$ & $36.5 \mathrm{~b}$ & $4.8 \mathrm{a}$ \\
\hline $\mathrm{CV}_{\text {subplots }}(\%)$ & - & - & 17.4 & 19.1 & 15.5 \\
\hline \multicolumn{6}{|l|}{ Cultivars } \\
\hline BR 125 & Means & 6.5 & $2.2 \mathrm{a}$ & 40.9 & 3.8 \\
\hline AG 1051 & Means & 5.3 & $2.5 \mathrm{a}$ & 41.4 & 3.9 \\
\hline $\mathrm{CV}_{\text {plots }}(\%)$ & - & - & 1.3 & 23.6 & 21.2 \\
\hline
\end{tabular}

${ }_{1 /}^{\prime}$ Means followed by the same letter are not significantly different at $5 \%$ probability by Tukey's test. ${ }^{2} /$ In the intercrop treatments, the leguminous species were broadcasting sowed between corn rows, simultaneously when the corn was sowed. The sowing rate for gliricidia (Gliricidia sepium) and sabiá (Mimosa caesalpiniifolia) intercrops was 30 viable seeds $\mathrm{m}^{-2}$. The sowing rate for corn + gliricidia + sabiá intercrop was 15 viable seeds $\mathrm{m}^{-2}$ of each leguminous species.

better than gliricidia, especially when grown in the absence of gliricidia (Table 2). Perhaps the fact that sabia is native to the Caatinga and thus is better adapted to the abiotic and biotic conditions of its semiarid climate than gliricidia explains its superiority (Maia, 2004). Different survival and growth rates between species contribute to the coexistence of different species in heterogeneous environments (Beckage \& Clark, 2003). The findings of these authors may help explain the increased gliricidia and sabiá root collar diameters when they were intercropped with corn in an environment that was highly heterogeneous with respect to weeds (Table 2).

There were effects of cultivars (C) and methods of weed control (M), but there was no effect of $\mathrm{C} \times \mathrm{M}$ interaction for the traits used for evaluation of baby corn yield. Weeding twice resulted in the best baby corn yields compared to the other treatments, which were not different from each other, except in the dry mass of the husked ears. For the dry mass of the husked ears, the gliricidia + sabia intercropping resulted in a yield that was intermediate between the yield obtained with two weedings and those of the other treatments. The baby corn characteristics analyzed were superior for cultivar BR 205 compared to cultivar AG 1051 (Table 3).

Also, in the total number and total weight of green ears there were effects of cultivars
(C) and methods of weed control (M), but there was no effect of $\mathrm{C} \times \mathrm{M}$ interaction. The means of the main effects of the two treatment groups are shown in Table 4. For the total number of green ears, performing two weedings produced the best results; intercropping with sabia produced an intermediate result; the other treatments, which did not differ from each other, produced the worst results. For the total green ear weight, the treatments involving intercropping produced yields intermediate between two weedings and no weeding. For both characteristics, cultivar BR 205 performed better (Table 4).

With regard to number and weight of marketables unhusked green ears there were effects of cultivars, methods of weed control and $\mathrm{C} \times \mathrm{M}$ interaction. That is, the cultivars responded differently to the weed control methods for these two characteristics (Table 5). Intercropping produced better yields for both characteristics in the absence of weeding for cultivar BR 205. For cultivar AG 1051, the yields from the intercroppings were equal to or lower than those obtained without weeding. The cultivars were not different from each other with or without weeding, but cultivar BR 205 was superior to cultivar AG 1051 when intercropped (Table 5).

As to number and weight of marketables husked green ears, the results were similar to those obtained with the number and weight 
Table 3 - Means for baby corn yield of corn cultivars as a response to weed control methods ${ }^{1} /$

\begin{tabular}{|c|c|c|c|c|}
\hline \multirow{2}{*}{ Weed control methods ${ }^{\underline{2}}$} & \multirow{2}{*}{$\begin{array}{l}\text { Total number of } \\
\text { ears per hectare }\end{array}$} & \multicolumn{3}{|c|}{ Weight of baby corn ears $\left(\mathrm{kg} \mathrm{ha}^{-1}\right)$} \\
\hline & & Fresh unhusked ears & Fresh husked ears & Dry husked ears \\
\hline Two hoeings & $72443 \mathrm{a}$ & 5517 a & $1118 \mathrm{a}$ & $123 \mathrm{a}$ \\
\hline Sabiá intercropping & $50490 \mathrm{~b}$ & $3239 \mathrm{~b}$ & $764 \mathrm{~b}$ & $84 \mathrm{~b}$ \\
\hline Gliricidia intercropping & $47964 \mathrm{~b}$ & $3157 \mathrm{~b}$ & $827 \mathrm{~b}$ & $90 \mathrm{~b}$ \\
\hline Sabiá + gliricidia intercropping & $48884 \mathrm{~b}$ & $3263 \mathrm{~b}$ & $755 \mathrm{~b}$ & $97 \mathrm{ab}$ \\
\hline No hoeing & $48035 \mathrm{~b}$ & $3052 \mathrm{~b}$ & $740 \mathrm{~b}$ & $87 \mathrm{~b}$ \\
\hline $\mathrm{CV}_{\text {subplots }}(\%)$ & 13.4 & 16.8 & 23.8 & 32.0 \\
\hline \multicolumn{5}{|l|}{ Cultivars } \\
\hline BR 125 & $60705 \mathrm{a}$ & $4388 \mathrm{a}$ & $933 \mathrm{a}$ & $108 \mathrm{a}$ \\
\hline AG 1051 & $46422 \mathrm{~b}$ & $2903 \mathrm{~b}$ & $749 \mathrm{~b}$ & $83 \mathrm{~b}$ \\
\hline $\mathrm{CV}_{\text {plots }}(\%)$ & 16.9 & 22.8 & 17.5 & 22.3 \\
\hline
\end{tabular}

${ }^{1 /}$ Means followed by the same letter are not significantly different at $5 \%$ probability by Tukey's test. 는 In the intercrop treatments, the leguminous species were broadcasting sowed between corn rows, simultaneously when the corn was sowed. The sowing rate for gliricidia (Gliricidia sepium) and sabiá (Mimosa caesalpiniifolia) intercrops was 30 viable seeds $\mathrm{m}^{-2}$. The sowing rate for corn + gliricidia + sabiá intercrop was 15 viable seeds $\mathrm{m}^{-2}$ of each leguminous species.

Table 4 - Means for green ears yield of corn cultivars as a response to weed control methods ${ }^{1 /}$

\begin{tabular}{|l|c|c|}
\hline \multirow{2}{*}{ Weed control methods ${ }^{-} /$} & \multicolumn{2}{|c|}{ Green ears unhusked per hectare } \\
\cline { 2 - 3 } & Total number & $\begin{array}{c}\text { Total weight } \\
(\mathrm{kg})\end{array}$ \\
\hline Two hoeings & $46855 \mathrm{a}$ & $11087 \mathrm{a}$ \\
\hline Sabiá intercropping & $42422 \mathrm{ab}$ & $8312 \mathrm{~b}$ \\
\hline Gliricidia intercropping & $40254 \mathrm{~b}$ & $7737 \mathrm{bc}$ \\
\hline Sabiá + gliricidia intercropping & $40142 \mathrm{~b}$ & $7302 \mathrm{bc}$ \\
\hline No hoeing & $40826 \mathrm{~b}$ & $7114 \mathrm{c}$ \\
\hline CV & 8.2 & 10.5 \\
\hline Cultivars & \multicolumn{2}{|c|}{} \\
\hline BR 125 & $42437 \mathrm{a}$ & $9007 \mathrm{a}$ \\
\hline AG 1051 & $41763 \mathrm{a}$ & $7614 \mathrm{~b}$ \\
\hline CV $_{\text {plots }}(\%)$ & 9.9 & 13.8 \\
\hline
\end{tabular}

${ }^{1 /}$ Means followed by the same letter are not significantly different at $5 \%$ probability by Tukey's test. ${ }^{2 /}$ In the intercrop treatments, the leguminous species were broadcasting sowed between corn rows, simultaneously when the corn was sowed. The sowing rate for gliricidia (Gliricidia sepium) and sabiá (Mimosa caesalpiniifolia) intercrops was 30 viable seeds $\mathrm{m}^{-2}$. The sowing rate for corn + gliricidia + sabiá intercrop was 15 viable seeds $\mathrm{m}^{-2}$ of each leguminous species.

of marketables unhusked green ears. That is, there were effects of cultivars (C), methods of weed control $(\mathrm{M})$ and $\mathrm{C} \times \mathrm{M}$ interaction. The numbers of ears of cultivar BR 205 were the same with two weedings and with intercropping with sabiá or gliricidia and greater than the numbers for the other two treatments (Table 6). For cultivar AG 1041, the number of ears obtained with two weedings was higher than the numbers obtained with the other treatments, which were not different from each other. The mass of the ears from cultivar BR 205 was higher with two weedings, intermediate for the sabia or gliricidia intercroppings, and lower for the other treatments. For the other cultivar, the mass of the ears was also highest with two weedings, lowest with no weeding, and intermediate for the other treatments (Table 6). Cultivar BR 205 was superior to cultivar AG 1041 in terms of the number and mass of marketable husked ears under all weed control methods, except for two weedings (number of ears) and the absence of weeding (number and mass of ears). The yields from the two cultivars were similar for these two treatments (Table 6).

There were no effects of cultivars $x$ methods of weed control interaction in the grain yield and its components. The highest corn grain yield was obtained with two weedings and the lowest with no weeding (Table 7). The intercroppings produced intermediate harvest yields. The maximum yield, obtained with two weedings, was associated with maximum values of all three main components of the yield. Similarly, the lowest yield, observed with no weeding, was attributed to decreases in the yield components. Cultivar BR 205 performed better than AG 1051 and this superiority was 
Table 5 - Means for green ears yield of corn cultivars as a response to weed control methods ${ }^{1 /}$

\begin{tabular}{|c|c|c|c|c|}
\hline \multirow{4}{*}{ Weed control methods ${ }^{\underline{2}}$} & \multicolumn{4}{|c|}{ Ears unhusked marketable ha ${ }^{-1}$} \\
\hline & \multirow{2}{*}{\multicolumn{2}{|c|}{$\begin{array}{c}\text { Number } \\
\text { Cultivars }\end{array}$}} & \multicolumn{2}{|c|}{ Weight (kg) } \\
\hline & & & \multicolumn{2}{|c|}{ Cultivars } \\
\hline & BR 105 & AG 1041 & BR 105 & AG 1041 \\
\hline Two hoeings & $30442 \mathrm{Aa}$ & $27564 \mathrm{Aa}$ & $8811 \mathrm{Aa}$ & $7728 \mathrm{Aa}$ \\
\hline Sabiá intercropping & $26947 \mathrm{Aa}$ & $21041 \mathrm{Bab}$ & $6909 \mathrm{Ab}$ & $4963 \mathrm{Bb}$ \\
\hline Gliricidia intercropping & 26135 Aab & $13322 \mathrm{Bc}$ & $6421 \mathrm{Abc}$ & $3046 \mathrm{Bc}$ \\
\hline Sabiá + gliricidia intercropping & $19631 \mathrm{Abc}$ & $13150 \mathrm{Bc}$ & 4928 Acd & $3075 \mathrm{Bc}$ \\
\hline No hoeing & $18133 \mathrm{Ac}$ & $19711 \mathrm{Abc}$ & $4251 \mathrm{Ad}$ & $4133 \mathrm{Abc}$ \\
\hline CV plots $(\%)$ & \multicolumn{2}{|c|}{17.9} & \multicolumn{2}{|c|}{26.4} \\
\hline $\mathrm{CV}_{\text {subplots }}(\%)$ & \multicolumn{2}{|c|}{17.2} & \multicolumn{2}{|c|}{15.5} \\
\hline
\end{tabular}

${ }^{1 /}$ Means followed by the same upper case letter in the row, and by the same lower case letter in the column do not differ from one another at $5 \%$ probability, by Tukey's test. ${ }^{2} /$ In the intercrop treatments, the leguminous species were broadcasting sowed between corn rows, simultaneously when the corn was sowed. The sowing rate for gliricidia (Gliricidia sepium) and sabiá (Mimosa caesalpiniifolia) intercrops was 30 viable seeds $\mathrm{m}^{-2}$. The sowing rate for corn + gliricidia + sabiá intercrop was 15 viable seeds $\mathrm{m}^{-2}$ of each leguminous species.

Table 6 - Means for green ears yield of corn cultivars as a response to weed control methods ${ }^{1}$ '

\begin{tabular}{|c|c|c|c|c|}
\hline \multirow{4}{*}{ Weed control methods ${ }^{\underline{2} /}$} & \multicolumn{4}{|c|}{ Ears husked marketable ha $^{-1}$} \\
\hline & \multicolumn{2}{|c|}{ Number } & \multicolumn{2}{|c|}{ Weight (kg) } \\
\hline & \multicolumn{2}{|c|}{ Cultivars } & \multicolumn{2}{|c|}{ Cultivars } \\
\hline & BR 105 & AG 1041 & BR 105 & AG 1041 \\
\hline Two hoeings & $26481 \mathrm{Aa}$ & $22435 \mathrm{Aa}$ & $5106 \mathrm{Aa}$ & $3976 \mathrm{Ba}$ \\
\hline Sabiá intercropping & 22333Aa & $15833 \mathrm{Bb}$ & $3435 \mathrm{Ab}$ & $2462 \mathrm{Bb}$ \\
\hline Gliricidia intercropping & $23076 \mathrm{Aa}$ & $11434 \mathrm{Bb}$ & $3688 \mathrm{Ab}$ & $1771 \mathrm{Bbc}$ \\
\hline Sabiá + gliricidia intercropping & $15213 \mathrm{Ab}$ & $9632 \mathrm{Bb}$ & 2335 Ac & $1547 \mathrm{Bbc}$ \\
\hline No hoeing & $13455 \mathrm{Ab}$ & $12232 \mathrm{Ab}$ & $2143 \mathrm{Ac}$ & $1856 \mathrm{Ac}$ \\
\hline $\mathrm{CV}_{\text {plots }}(\%)$ & \multicolumn{2}{|c|}{18.0} & \multicolumn{2}{|c|}{24.7} \\
\hline $\mathrm{CV}_{\text {subplots }}(\%)$ & \multicolumn{2}{|c|}{20.3} & \multicolumn{2}{|c|}{13.9} \\
\hline
\end{tabular}

${ }_{1}^{1 /}$ Means followed by the same upper case letter in the row, and by the same lower case letter in the column do not differ from one another at 5\% probability, by Tukey's test. ㄴ In the intercrop treatments, the leguminous species were broadcasting sowed between corn rows, simultaneously when the corn was sowed. The sowing rate for gliricidia (Gliricidia sepium) and sabiá (Mimosa caesalpiniifolia) intercrops was 30 viable seeds $\mathrm{m}^{-2}$. The sowing rate for corn + gliricidia + sabiá intercrop was 15 viable seeds $\mathrm{m}^{-2}$ of each leguminous species.

Table 7 - Means for grain yield and its components of corn cultivars as a response to weed control methods ${ }^{1 /}$

\begin{tabular}{|l|c|c|c|c|}
\hline \multicolumn{1}{|c|}{ Weed control methods ${ }^{2}$} & $\begin{array}{c}\text { Grain yield } \\
\left(\mathrm{kg} \mathrm{ha}^{-1}\right)\end{array}$ & Ear number per ha & $\begin{array}{c}\text { Kernel number } \\
\text { per ear }\end{array}$ & $\begin{array}{c}100 \text {-kernel weight } \\
(\mathrm{g})\end{array}$ \\
\hline Two hoeings & $4589 \mathrm{a}$ & $35962 \mathrm{a}$ & $418 \mathrm{a}$ & $28.5 \mathrm{a}$ \\
\hline Sabiá intercropping & $3536 \mathrm{~b}$ & $30930 \mathrm{ab}$ & $374 \mathrm{ab}$ & $23.4 \mathrm{~b}$ \\
\hline Gliricidia intercropping & $2735 \mathrm{bc}$ & $27404 \mathrm{~b}$ & $379 \mathrm{ab}$ & $26.4 \mathrm{ab}$ \\
\hline Sabiá + gliricidia intercropping & $2964 \mathrm{bc}$ & $26875 \mathrm{~b}$ & $354 \mathrm{~b}$ & $25.0 \mathrm{~b}$ \\
\hline No hoeing & $2564 \mathrm{c}$ & $28077 \mathrm{~b}$ & $346 \mathrm{~b}$ & $24.7 \mathrm{~b}$ \\
\hline CV & 22.0 & 14.6 & 12.6 & 8.4 \\
\hline Cultivars & \multicolumn{3}{|c|}{} \\
\hline BR 125 & $3705 \mathrm{a}$ & $31096 \mathrm{a}$ & $406 \mathrm{a}$ & $25.7 \mathrm{a}$ \\
\hline AG 1051 & $2850 \mathrm{~b}$ & $28603 \mathrm{a}$ & $342 \mathrm{~b}$ & $26.3 \mathrm{a}$ \\
\hline CV & 23.4 & 12.8 & 16.4 & 7.7 \\
\hline
\end{tabular}

${ }^{1 /}$ Means followed by the same letter do not differ from one another at $5 \%$ probability, by Tukey's test. ${ }^{2 /}$ In the intercrop treatments, the leguminous species were broadcasting sowed between corn rows, simultaneously when the corn was sowed. The sowing rate for gliricidia (Gliricidia sepium) and sabiá (Mimosa caesalpiniifolia) intercrops was 30 viable seeds $\mathrm{m}^{-2}$. The sowing rate for corn + gliricidia + sabiá intercrop was 15 viable seeds $\mathrm{m}^{-2}$ of each leguminous species. 
attributed to the greater number of ears per ha and greater weight of 100 corn grains (Table 7).

The two treatment types (cultivar and weed control method) affected baby corn (Table 1), green corn (Tables 2 to 6), and corn grain (Table 7) yields differently. There are at least three reasons for these differences. First, these products are harvested at different times, i.e., these types of corn compete with other species for various amounts of time and under different environmental conditions. Second, the products are evaluated differently. Finally, phenological differences may affect the yield of the three products. Reid et al. (2014) found that delays in controlling weeds increased the interval between male and female flowering. This increase should not affect baby corn yields, but may negatively impact green corn and corn grain yields because of occasional pollination problems.

The numbers and masses of marketable unhusked (Table 5) and husked ears (Table 6) of the cultivars did not differ in the absence of weeding or with two weedings (except for the mass of marketable husked ears, Table 6). In other words, for the intercroppings, cultivar BR 205 always performed better than cultivar AG 1041, suggesting that cultivar BR 205 is better adapted to the intercropping conditions. There are differences in how various cultivars behave in intercropping, including for weed control (Kuchinda et al., 2003; Olowe $\&$ Adeyemo, 2009), and in some cases, these differences may be related, at least partially, to the prolificacy observed in corn.

Prolificacy is the ability of the corn plant to produce more than one ear per stalk. It is determined genetically and allows the plant to produce more ears under stressful conditions (e.g., high plant density, nutritional deficiency, competition with weeds). Higher corn grain yields from corn breeds and hybrids are associated with a higher number of ears per plant under stressful conditions (Betrán et al., 2003). Weeds cause stress to crops by competing for resources necessary for growth and by allelopathy. Mahajan et al. (2007) found that corn produced fewer ears per stalk when weeds were not controlled.
It is expected that there is a relationship between prolificacy and the production of new female inflorescences as the latter are removed, but this relationship was not found in the literature consulted. Cultivar BR 205 was, on average, superior to cultivar AG 1051 for all of the characteristics used to analyze baby corn yield (Table 3 ), in the number and mass of green ears (Table 4), in the number and mass of marketable green ears, both unhusked and husked (with various methods of weed control) (Tables 5 and 6), and in corn grain yield (Table 7 ). The superiority of one cultivar over another depends on many characteristics. One characteristic that may help explain the superiority of cultivar BR 205 is its higher prolificacy. For example, with a planting density of 50,000 plants ha ${ }^{-1}$, cultivar BR 205 produced 60,705 baby corn ears ha $^{-1}$ and cultivar AG 1051 produced 46,422 baby corn ears ha-1 (Table 3).

Performing two weedings to eliminate the majority of the weeds resulted in the best yields of baby corn (Table 3), green corn (Tables 4, 5 and 6) and corn grain (Table 7). For cultivar BR 205, intercropping with sabiá produced results similar to those obtained with two weedings for the number of marketable unhusked ears (Table 5). Sabia was the second best treatment in terms of the total number and mass of green ears for both cultivars (Table 4), the number of marketable husked and unhusked ears for cultivar AG 1041 (Tables 5 and 6), and the masses of marketable unhusked (Table 5) and husked ears (Table 6) and corn grain yield (Table 7) for both cultivars. The intercropping with gliricidia yielded a number of marketable husked ears equal to that with two weedings (Table 6) and was often the third best treatment when considering baby corn, green corn and corn grain yields. Intercropping with gliricidia + sabiá was better than the "no weeding" treatment for the total mass of green ears (Table 4), the number and mass of marketable husked ears of cultivar AG 1041 (Table 6), and the corn grain yields for both cultivars (Table 7).

Therefore, of the three intercroppings analyzed, corn - sabiá was the best, followed by corn - gliricidia, and then corn sabiá + gliricidia, when considering the 
characteristics used to evaluate corn yield. Sabiá may have a better competitive ability and its allelochemicals (Piña-Rodrigues \& Lopes, 2001) may be more effective than gliricidia for controlling the weed species that occurred in the experiment, as suggested by its better survival and taller plant height (Table 1). The hypothesis of the present study was that intercropping with a combination of sabiá + gliricidia would control weeds better than intercropping with sabiá or gliricidia alone, similar to what often occurs with a mixture of plant residues or extracts. This hypothesis was not confirmed and there are several potential reasons. First, the interference between sabia and gliricidia plants may be stronger than the interference among sabia plants or among gliricidia plants, resulting in decreased effectiveness in weed control with the corn - sabiá + gliricidia intercropping. Second, the fact those combinations of extracts or plant residues are more effective than extracts or plant residues used individually may be associated with the higher concentrations of allelochemicals in the extracts and plant residues compared to those secreted by plants. Finally, processes that are not performed by extracts or residues occur in live plants.

Weeds reduced the yield of baby corn (Table 3), green ears (Tables 4 to 6), and corn grain (Table 7 ). Weeds decrease the yield of crops competing for water, nutrients, and light.

It can be concluded that performing two weeding reduces weed growth and determines the highest yields of baby corn, green corn and corn grain. Intercropping do not reduces weed growth. When considering the characteristics used for evaluating corn yield, the corn-sabiá intercropping is the best, followed by the corngliricidia intercropping, and lastly by the cornsabiá + gliricidia intercropping. The cultivars do not differ in regards to the reduction in weed growth, the number and mass of marketable unhusked ears and the mass of marketable husked ears. For all other characteristics, the cultivar BR 205 is the best.

\section{LITERATURE CITED}

BECKAGE, B.; CLARK, J. S. Seedling survival and growth of three forest tree species: the role of spatial heterogeneity. Ecology, v. 84, n. 7, p. 1849-1861, 2003.
BETRÁN, F. J. et al. Secondary traits in parental inbreds and hybrids under stress and non-stress environments in tropical maize. Field Crops Res., v. 83, n. 1, p. 51-65, 2003.

CARMO FILHO, F.; OLIVEIRA, O. F. Mossoró: um município do semi-árido nordestino. Mossoró: Fundação Guimarães Duque/ESAM, 1989. 62 p. (Coleção Mossoroense, Série B, 672).

EBANA, K. et al. Variation in the allelopathic effect of rice with water soluble extracts. Agron. J., v. 93, n. 1, p. 12-16, 2001.

EMPRESA BRASILEIRA DE PESQUISA AGROPECUÁRIA - EMBRAPA. Centro Nacional de Pesquisa do Solo. Sistema brasileiro de classificação de solos. Brasília: Serviço de Produção de Informação, 2006. 306 p.

IMATOMI, M.; NOVAES, P.; GUALTIERI, S. C. J. Interspecific variation in the allelopathic potential of the family Myrtaceae. Acta Bot. Bras., v. 27, n. 1, p. 54-61, 2013.

KHALIQ, A. et al. Effect of crop residues applied isolated or in combination on the germination and seedling growth of horse purslane (Trianthema portulacastrum).

Planta Daninha, v. 29, n. 1, p. 121-128, 2011.

KHAN, M. A. et al. Bioherbicidal effects of tree extracts on seed germination and growth of crops and weeds. Pakistan J. Weed Sci. Res., v. 11, n. 3-4, p. 89-94, 2005.

KUCHINDA, N. C. et al. On-farm evaluation of improved maize varieties intercropped with some legumes in the control of Striga in the Northern Guinea savanna of Nigeria.

Crop Protec., v. 22, n. 3, p. 533-538, 2003.

MAHAJAN, G. et al. Effect of plastic mulch on economizing irrigation water and weed control in baby corn sown by different methods. African J. Agric. Res., v. 2, n. 1, p. 19-26, 2007.

MAIA, G. N. Caatinga: árvores e arbustos e suas utilidades. São Paulo: D\&Z Computação, 2004. 413 p.

MATLOOB, A. et al. Quantification of allelopathic potential of different crop residues for the purple nutsedge supression. Pakistan J. Weed Sci. Res., v. 16, n. 1, p. 1-12, 2010.

MUBEEN, K. et al. Allelophatic effects of sorghum and sunflower water extracts on germination and seedling growth of rice (Oriza sativa L.) and three weed species. J. Anim. Plant Sci., v. 22, n. 3, p. 738-746, 2012.

OLOWE, V. I. O.; ADEYEMO, A. Y. Enhanced crop productivity and compatibility through intercropping of sesame and sunflower varieties. Ann. Appl. Biol., v. 155, n. 2, p. 285-291, 2009.

Planta Daninha, Viçosa-MG, v. 33, n. 4, p. 717-726, 2015 
PIÑA-RODRIGUES, F. C. M.; LOPES, B. M. Potencial alelopático de Mimosa caesalpinaefolia Benth. sobre sementes de Tabebuia alba (Cham.) Sandw. Flor. Amb., v. 8, n. 1, p. 130-136, 2001.

RAJASHEKARAPPA, K. S.; BASAVARAJAPPA, B. E.; PUTTAIAH, E. T. Effect of different organic mulches and in situ green manuring on soil properties and yield and economics of maize in south-eastern dry zone of Karnataka. Glob. J. Biol. Agric. Health Sci., v. 2, n. 3, p. 236-240, 2013.

REID, A. et al. Delaying control lengthens the anthesis-silkink interval in maize. Weed Sci., v. 62, n. 2, p. 326-337, 2014.

SILVA, P. S. L. A. et al. Green ear yield and grain yield of maize after harvest of the first ear as baby corn. Hort. Bras., v. 24, n. 2, p. 151-155, 2006.
TAVELLA, L. B. et al. Weed control in corn and weed sample size for growth evaluations. Planta Daninha, v. 32, n. 1, p. 51-59, 2014.

UDDIN, M. R. et al. Combined herbicidal effect of two natural products (sorgoleone and hairy root extracts of tartary buckwheat) on crops and weeds. Austr. J. Crop Sci., v. 7, n. 2, p. 227-233, 2013.

VALKONEN, S. Survival and growth of planted and seeded oak (Quercus robur L.) seedlings with and without shelters on field afforestation sites in Finland. For. Ecol. Manage., v. 255, n. 3-4, p. 1085-1094, 2008.

WANG, J. et al. Factors influencing establishment by direct seeding of indigenous tree species in typical plantations and shrubland in South China. New For., v. 42, n. 1, p. 19-33, 2011. 